\title{
A NOVEL HERBAL EXTRACT MEDICINE FOR LIVER HEMOSTASIS: AN EXPERIMENTAL ANIMAL STUDY
}

\author{
KARACIĞER HEMOSTAZINDA YENI BIR BITKISEL ILAÇ: DENEYSEL BIR HAYVAN \\ ÇALIŞMASI
}

\author{
Enver KUNDUZ1 (D), Zeyneb Afra DiNÇEL² (D), Büşra ŞEKER² (D), Hatice Kübra SAYLAK² (D), Okan DEMIR ${ }^{3}$ (D), \\ Hüseyin AKBULUT ${ }^{1}$ (D), Erhan AYŞAN ${ }^{4}$ (D) \\ ${ }^{1}$ Bezmialem Vakif University, Faculty of Medicine, General Surgery Department, Istanbul, Turkey \\ ${ }^{2}$ Bezmialem Vakif University, Faculty of Medicine, Istanbul, Turkey \\ ${ }^{3}$ Yeditepe University, Bioengineering Deparment, Istanbul, Turkey \\ ${ }^{4}$ Yeditepe University, Faculty of Medicine, General Surgery Department, Istanbul, Turkey
}

ORCID IDs of the authors: E.K. 0000-0002-7686-2809; Z.A.D. 0000-0002-7915-3362; B.Ş. 0000-0002-2548-1213; H.K.S. 0000-0002-7437-7404; O.D. 0000-0001-9118-6426; H.A. 0000-0003-0296-3751; E.A. 0000-0002-9563-3761

Cite this article as: Kunduz E, Dinçel ZA, Şeker B, Saylak KK, Demir O, Akbulut H, et al. A novel herbal extract medicine for liver hemostasis: an experimental animal study. J Ist Faculty Med 2019;82(3):156-61. doi: 10.26650/IUITFD.2019.0014

\begin{abstract}
Objective: Bleeding is one of the major complications of surgical procedures. Severe bleeding can be seen after liver injury. Various methods have been described in the literature for stopping liver bleeding such as compression, Pringle maneuver, and other hemostatic agents have been used.

In this study, the use of anti-inflammatory, antioxidant, antimicrobial, analgesic, and anticoagulant agents described in the literature were evaluated for hemostatic efficacy following liver injuries.
\end{abstract}

Materials and Methods: In this study 28 Wistar albino female I male rats from out-bred production were used. Animals were divided in 4 groups. After liver damage model creation, various herbal substances were applied to the liver. Hematocrit and platelet counts were measured. In addition, for histopathologic changes in the liver parenchyma, the rats were sacrificed, and the liver was resected.

Results: The amount of bleeding (p:0.001) and the preoperative and postoperative hematocrit changes ( $p: 0.009$ ) were statistically significant between the groups. There was no significant difference in connective tissue growth (p:0.065) and necrosis (p:0.062). There were significant differences in inflammation and without karyorrhexis (p:0.003).

Discussion: Histopathological examinations showed that the groups using active agents had more connective tissue and karyorrhexis. Therefore these tissues could help to stop bleeding.

Keywords: Liver bleeding, Herbal medicine, hemostatic agent

\section{ÖZET}

Amaç: Kanama, cerrahi işlemlerin ana komplikasyonlarından biridir. Karaciğer hasarı sonrası ciddi kanamalar görülebilir. Literatürde kompresyon, Pringle manevrası ve diğer hemostatik ajanlar gibi karaciğer kanamasını durdurmak için çeşitli yöntemler tanımlanmıştır.

Bu çalışmada, literatürde anti-enflamatuar, antioksidan, antimikrobiyal, analjezik ve antikoagülan etkileri gösterilmiş ajanların kullanımının, karaciğer yaralanmalarında hemostatik etkinlikleri değerlendirildi.

Gereç ve Yöntem: Bu çalışmada 28 adet Wistar albino dişi / erkek sıçan kullanıldı. Hayvanlar 4 gruba ayrıldı. Karaciğer hasarı modeli oluşturulduktan sonra, karaciğere çeşitli bitkisel karışımlar uygulandı. Hematokrit ve trombosit sayıları ölçüldü. Ayrıca karaciğer parankimindeki histopatolojik değişiklikler için, sıçanlar sakrifiye edilerek karaciğer rezeke edildi.

Bulgular: Kanama miktarı (p:0,001) ve preoperatif ve postoperatif hematokrit değişiklikleri (p:0,009) gruplar arasında istatistiksel olarak anlamlıydı. Bağ dokusu büyümesinde (p:0,065) ve nekrozda anlamlı bir fark yoktu (p:0,062). Karyorreksis olmadan iltihaplanmada anlamlı fark vardı (p:0,003).

Tartışma: Histopatolojik incelemeler aktif ajan kullanan grupların daha fazla bağ dokusu ve karyorreksi, kanamayı durdurmaya yardım edebilmektedir.

Anahtar Kelimeler: Karaciğer kanaması, Bitkisel ilaç, hemostatik ajan

Illetişim kurulacak yazar/Corresponding author: drkunduz@yahoo.com

Submitted/Başvuru: 05.02.2019• Revision Requested/Revizyon Talebi: 15.02.2019•

Last Revision Received/Son Revizyon: 15.02.2019 • Accepted/Kabul: 26.03.2019 • Published Online/Online Yayın: 29.03 .2019

(C) Telif Hakkı $2019 \mathrm{~J}$ Ist Faculty Med - Makale metnine jmed.istanbul.edu.tr web sayfasından ulaşılabilir.

(C) Copyright 2019 by J Ist Faculty Med - Available online at jmed.istanbul.edu.tr 


\section{INTRODUCTION}

Bleeding is one of the major complications of surgical procedures (1). Severe bleeding can be seen after liver injury because of the vascularity of the liver and sinusoidal structure which is not suitable for vasoconstriction and also veins do not have a valve structure. Bile leaking from the injured surface of the liver also increases perioperative morbidity in emergency and elective hepatic surgeries by inhibiting coagulation (2-4). However, the major problem with the liver is oozing hemorrhage from the liver surface and from small vessels $(3,4)$.

Various methods have been described in the literature for stopping liver bleeding such as packing, Pringle maneuver, and other hemostatic agents have been used (5-9). Another important problem in patients who undergo liver surgery are infections that develop after hemorrhage. Control of infections is an important factor affecting mortality and morbidity after liver surgery (10).

Many herbal medicine agents which have anti-inflammatory, antimicrobial, antioxidant, antineoplastic, analgesic, and anticoagulant activity are described in the literature (11-14). Reducing the warfarin effect of Hypericum perforatum (HP) (St. John's wort), the antimicrobial, anti-inflammatory (11), analgesic and antioxidant effects of Urtica dioica (UD) (stinging nettle) (12), the antibacterial, antiviral, antioxidant, antineoplastic and anti-inflammatory (13) effects of Cocos nucifera, reducing inflammation, increasing collagen muscle activity of Vitellaria paradoxa (VP) (14), the very important role in wound healing of zinc oxide (15), and the antibacterial, antifungal, anti-inflammatory and antioxidant effects of Thymus vulgaris (TD) (16) have been proven by scientific studies.

In this study, the use of anti-inflammatory, antioxidant, antimicrobial, analgesic, and anticoagulant agents described in the literature were evaluated for hemostatic efficacy following liver injuries.

\section{MATERIAL AND METHODS}

This research was carried out in the Laboratory of Experimental Animal Production and Research at the Faculty of Medicine of Bezmialem University after the approval of the local animal ethics committee. In this study 28 Wistar albino female / male rats weighing $180 \pm 15 \mathrm{~g}$, five months old, and from out-bred production were used. The rats were fed with a pellet-type feed specially produced for experimental animals, with the rats incubated in the experimental animal production cages with the base of the rats and the plastic wool on the side and the iron wire braided on the sides.

Peripheral blood was collected one week before the hepatic parenchymal damage model was performed in all rats and hematocrit and hemoglobin values were checked.

\section{Liver Failure model}

After overnight fasting, the rats were anesthetized for 45-60 seconds in an ether-containing jar. Anesthesia was continued with subcutaneous ketamine at a dose of 75 $\mathrm{mg} / \mathrm{kg}$. The abdomen midline was shaved after the incision was applied, followed by antisepsis with povidone iodine. A $3 \mathrm{~cm}$ vertical midline incision starting just below the xiphoid was introduced into the peritoneal cavity. Before modeling, a nylon bag cut into the funnel was placed under the liver and the entire surgical procedure was performed on a panel with a $30^{\circ}$ downward slope. Thus, all the blood from the parenchyma of the liver was collected in the bag.

The rat liver has four lobes and the left lateral lobe which is the widest surface of the liver was selected for the experimental model. The left lateral lobe mid hump was completely cut into two anatomically. The sacrificed distal section was discarded. The parenchymal surface of the proximal section was compressed with a gauze fabric of $2 \times 2 \mathrm{~cm}$ size, made of standard cotton fabric, at medium pressure to stop the bleeding for 3 minutes. Three minutes later, the gauze was lifted and we waited for 5 minutes without any intervention to the liver or bleeding centers. During this time, the amount of blood collected into the nylon bag was recorded as the amount of perioperative bleeding. After the time had elapsed, the bag was taken out of the abdominal cavity. After the liver parenchymal damage was established, the rats were divided into four equal groups according to the hemostatic agents to be administered. After applications the midline incision of the abdomen of all rats was closed with continuous suture technique using 3/0 polypropylene (Prolen ${ }^{\circledR}$, Kurtsan Co.).

\section{Preparation of the mixtures and identification of the groups}

The active ingredients and auxiliary substances were mixed to the extent that they could homogenize each other. The dosages of the substances were obtained from previous studies. The substances were prepared in $\mathrm{w} / \mathrm{w}$ measurement unit ( $\mathrm{w} / \mathrm{w}$ : weight of solute (gram) / Total weight of solute and solvent x100). All medicines were prepared in Genetics and Biomedical Labarotuary of Yeditepe University.

After the non-anatomical liver resection was performed on the rats in Group 1, saline was applied to the incision surface. The rats in Group 2 were treated with only auxiliary substances (5\% w/w VP, 5\% w/w coconut oil, 4\% $\mathrm{W} / \mathrm{w}$ emulgate $\mathrm{SE}-\mathrm{PF}, 4 \%$ glycerin) after non-anatomic liver resection. The third group of rats was treated with non-anatomical liver resection, and then active ingredients and auxiliary substances (5\% w/w catechin oil, $5 \%$ 
$\mathrm{w} / \mathrm{w}$ coconut oil, $4 \% \mathrm{w} / \mathrm{w}$ emulgate $\mathrm{SE}-\mathrm{PF}, 4 \%$ glycerin, $6 \% \mathrm{w} / \mathrm{w}$ zinc oxide, $4 \% \mathrm{w} / \mathrm{w}$ stevia oil, $3 \% \mathrm{w} / \mathrm{w}$ thyme oil, and $3 \% \mathrm{w} / \mathrm{w}$ nettle seed oil) were applied. For Group 4 mixture of the active ingredients (\%1 w/w Zinc oxide, $1 \% \mathrm{w} / \mathrm{w}$ Chitosan, 10\% w/w HP oil, 3\% w/w thyme oil) and auxiliary substances (7\% w/w VP oil, $5 \% \mathrm{w} / \mathrm{w}$ coconut oil, 5\% w/w emulgate SE-PF, 5\% w/w glycerin $\% 0.8$ w/w hydroxyethylcellulose, $1 \%$ w/w Cosmedia sp.) were used after liver damage. Groups were summarized in Table 1.

Table 1. Contents of the groups.

\begin{tabular}{|c|c|}
\hline Groups & Substances used \\
\hline Group 1 & Saline \\
\hline \multirow[t]{4}{*}{ Group 2} & $5 \%$ w/w VP \\
\hline & $5 \%$ w/w coconut oil \\
\hline & $4 \% \mathrm{w} / \mathrm{w}$ emulgate SE-PF \\
\hline & $4 \%$ glycerin \\
\hline \multirow[t]{8}{*}{ Group 3} & $5 \% \mathrm{w} / \mathrm{w}$ catechin oil \\
\hline & $5 \%$ w/w coconut oil \\
\hline & $4 \% \mathrm{w} / \mathrm{w}$ emulgate SE-PF \\
\hline & $4 \%$ glycerin \\
\hline & $6 \% \mathrm{w} / \mathrm{w}$ zinc oxide \\
\hline & $4 \%$ w/w stevia oil \\
\hline & $3 \% \mathrm{w} / \mathrm{w}$ thyme oil \\
\hline & $3 \% \mathrm{w} / \mathrm{w}$ nettle seed oil \\
\hline \multirow[t]{10}{*}{ Group 4} & $1 \%$ w/w Zinc oxide \\
\hline & $1 \%$ w/w Chitosan \\
\hline & $10 \%$ w/w HP oil \\
\hline & $3 \% \mathrm{w} / \mathrm{w}$ thyme oil \\
\hline & 7\% w/w VP oil \\
\hline & $5 \%$ w/w coconut oil \\
\hline & $5 \% \mathrm{w} / \mathrm{w}$ emulgate SE-PF \\
\hline & $5 \%$ w/w glycerin \\
\hline & $\% 0.8 w / w$ hydroxyethylcellulose \\
\hline & 1\% w/w Cosmedia sp. \\
\hline
\end{tabular}

\section{Postoperative care and histopathological examination} All rats were taken to their cages postoperatively and fed with standard feed and water. Hematocrit and platelet counts were measured by taking a peripheral blood sample from the rats 24 hours postoperatively and on the seventh postoperative day. In addition, for histopathologic changes in the liver parenchyma, the rats were sacrificed, and the liver was resected. Liver tissues fixed with $70 \%$ alcohol were stained with hematoxylin and eosin stain and examined by light microscopy at a magnification of 100x, necrosis rate, karyorrhexis, increase rate of connective tissue, $10 \%$ were rated " 0 ", $10-25 \%$ were rated " 1 ", $25 \%-50 \%$ were rated " 2 " and 50\%, were rated with a score of " 3 ".

\section{Statistical analysis}

The SPSS 15.0 (Armonk, NY, USA) was used for the statistical analysis. Descriptive statistics were given as number and percentage for categorical variables, and an average, standard deviation, and median for numeric variables. In the evaluation of the data, the dunn multiple comparison test was used to compare the two groups as well as the Kruskal-Wallis test. The results were evaluated at the level of significance $\mathrm{p}<0.05$.

\section{RESULTS}

Table 2 shows that the amount of bleeding and the preoperative and postoperative hematocrit changes were statistically significant between the groups. In the sub-analyzes, it was investigated which groups these differences originate from. Bleeding rates were found to be significantly higher in Group 3 according to Group 4, in Group 1 according to Group 4, in Group 2 according to Group 3, and in Group 1 according to Group 2 (respectively p:0.002, p:0.019, p:0.029, p:0.025). For hematocrit changes, Group 4 had a significant decrease in hematocrit values than Group 2 (p:0.011).

When histopathological examinations were compared among the groups, it was found that karyorrhexis was significantly different ( $p: 0.003$ ). It was determined that there was a significant difference between Group 2 and Group 4 in the subgroup and analyzes were performed to find out which group this source was from (p:0.002). The effect of the substance used in Group 4 on inflammation and without karyorrhexis was statistically significant compared to the substance used in Group 2.

Table 2. Evaluation of bleeding parameters between groups.

\begin{tabular}{llllll}
\hline & Group 1 (n:7) & Group 2 (n:7) & Group 3 (n:7) & Group 4 (n:7) & p value \\
Bleeding $(\mathrm{ml})($ mean $\pm \mathrm{SD})$ & $1.57 \pm 0.34$ & $0.61 \pm 0.39$ & $1.57 \pm 0.53$ & $0.58 \pm 0.25$ & 0.001 \\
Hemoglobin exchange $(\mathrm{g} / \mathrm{dl})($ mean $\pm \mathrm{SD})$ & $1.80 \pm 1.25$ & $0.94 \pm 0.45$ & $1.00 \pm 1.36$ & $1.55 \pm 0.63$ & 0.246 \\
Hemotocrite exchange $(\%)($ median) & 4.12 & 3.70 & 3.54 & 9.45 & 0.009 \\
Platelets $\left(\mathrm{K} / \mathrm{mm}^{3}\right)($ mean $\pm \mathrm{SD})$ & $269.71 \pm 379.34$ & $166.42 \pm 34.29$ & $193.50 \pm 80.55$ & $218.57 \pm 109.15$ & 0.301 \\
\hline
\end{tabular}


Table 3. Evaluation of histopathological examinations between groups

\begin{tabular}{llllll}
\hline & Group 1 (n:7) & Group 2 (n:7) & Group 3 (n:7) & Group 4 (n:7) & p value \\
Necrosis (median) (min-max) & $2.0(0-3)$ & $1.0(0-2)$ & $2.5(0-3)$ & $0.0(0-2)$ & 0.062 \\
Fibrosis (median) (min-max) & $1.0(1-2)$ & $3.0(1-3)$ & $1.5(1-2)$ & $1(0-3)$ & 0.065 \\
Karyorrhexis (median) (min-max) & $1.0(1-3)$ & $3.0(1-3)$ & $2.0(1-3)$ & $0.0(0-1)$ & 0.003 \\
\hline
\end{tabular}

There was no significant difference in connective tissue growth ( $p: 0.065)$ and necrosis ( $p: 0.062)$ when compared the groups to Kruskal Wallis test. Histopathological results were shown in Table 3.

\section{DISCUSSION}

Hemorrhages that may occur during emergency or elective surgical interventions are feared complications. High-volume hemorrhages can be observed, mainly because of the structure and blood supply of the liver during liver surgery (1-4).

Although many agents have been identified for hemostasis from liver surgery, the number of randomized human trials is very low due to ethical problems. Therefore, the experimental planning of the agents that we utilize synergistically from our work, antimicrobial, anti-inflammatory, anti-hemorrhagic and antioxidant effects and evaluate the activity in major liver cancers is planned as an animal study.

The general mechanism of action of many agents used as local bleeding stoppers is to provide a plug related to the foreign body reaction, to assist in the release of mediators that activate thrombocytes, to initiate natural hemostatic processes, to provide adhesion with fibrin formation, or vasoconstrictor effects (17).

Oils and plant extracts obtained from plants have been used for the treatment of diseases for thousands of years. There are many publications in the literature about the effects of HP, UD, zinc oxide and TD, which we assessed to be effective after being used together in our study. The use of HP as a medicine has been used since ancient times (18). Since then, it has been used frequently in the treatment of depression, anxiety, cuts, and burns $(18,19)$. In recent years, HP has been shown to be effective in the treatment of cancer, inflammatory diseases, viral and bacterial diseases, and may be used as an antioxidant (18, 20-23). In some studies of drug interactions with HP, it has been reported that HP enhances hepatic and intestinal enzymes, thereby contributing to the elimination of drugs or the conversion to inactive forms (18). HP, which has been used for thousands of years in wound healing, has also been observed fibroblasts of chicken in a caliche performed polygonal shape activation of the fibroblasts responsible for collagen production and wound closure after exposure to HP (24). HP's activity on warfarin has been reported to significantly increase the rate of clearing of both $\mathrm{S}$-warfarin and $\mathrm{R}$-warfarin in a recent study (11).

UD has been used since ancient times as an anti-rheumatic, as an analgesic and anti-inflammatory agent in the treatment of arthritis, as an antimicrobial and hemostatic agent in injuries $(25,26)$. In addition to these effects of UD in recent years, it has also been shown to be effective in the treatment of benign prostatic hypertrophy (27). A study on the mechanism of action of UD has shown that UD reduces root production of thromboxanes in platelets and herb extracts provide 12-LOX inhibition. Both extracts activate the MyD88 / NF-кB / p38 MAPK defects in the intestinal epithelium, thereby increasing the release of chemokines. Root extracts inhibit LPS-induced proinflammatory cytokine release and COX-2 expression, preserving tissue damage caused by inflammatory processes (25). One of the active ingredients of Ankaferd Blood Stopper ${ }^{\circledR}$ (ABS), which is used in the market as a bleeding stopper, is UD (28). In a study on the use of ABS in an experimental liver injury model, fewer gore bleeding and fewer hematocrites were detected in the control group of rats using ABS after liver injury (17).

Zinc is an element used for thousands of medical purposes (29). Many studies have shown that zinc is present in varying degrees in viable cells, and that it is involved in the structures of enzymes that play a role in repair after cell death, protein synthesis, and injury $(30,31)$. Zinc has an important role in wound healing (15). In an experimental rat wound model, it was observed that in the first 24 hours after wound formation, the amount of zinc on the wound surface increased by $15-20 \%$, and when the granulation tissue was the most and when the epidermal proliferation was observed, it increased by $30 \%$ (32). While zinc acts antimicrobially for many bacteria at the same time, it also inhibits the formation of nitric oxide and thus has an anti-inflammatory effect (32). There are many studies on the use of zinc in surgical patients. Patients who have undergone a surgical procedure have been shown to have more wound infection, wound dehiscence and impaired wound healing in patients with low serum zinc levels and low zinc levels (33). In another case, an area of patients with major vessel reconstruction were preoperatively and postoperatively treated with zinc, and patients treated with zinc had less complicated wound complications than the placebo gore (34). 
Antimicrobial, antifungal, anti-inflammatory and antioxidant effects of TV have been reported in studies $(16,35)$. It is also one of the main components of ABS in TV, like UD.

In our study, the combination of these agents was shown to cause less bleeding in Group 3 and 4 comparing to control groups (Group 1 and 2). It is also observed that the hemoglobin values are less statistically different, but the hematocrit exchange levels are significantly higher in the control groups and Group 4 according to Group 3. Again, although we do not have statistical significance, we think that the active agents are used in groups where the blood platelet values are tacked up to stop the bleeding. Histopathological examinations showed that the groups using active agents had more connective tissue and karyorrhexis than the other control groups. Therefore these tissues could help to stop bleeding.

\section{CONCLUSION}

As a result, $H P, U D$, zinc oxide and TV, which are currently used for medicine for various purposes with different activities, are expected to be used for the purpose of providing hemorrhage control, but more and larger sized animals must be studied before human studies.

Ethics Committee Approval: Ethics committee approval was received for this study from the local ethics committee.

Informed Consent: Written consent was obtained from the participants.

Peer Review: Externally peer-reviewed.

Author Contributions: Conception/Design of Study- E.A., E.K.; Data Acquisition- E.A., E.K., O.D., H.A.; Data Analysis/Interpretation- R.D., D.Ş., H.S., O.D., H.A.; Drafting Manuscript- E.A., E.K.; Critical Revision of Manuscript- R.D., D.Ş., H.S., O.D.; Final Approval and Accountability- E.K., E.A.; Technical or Material Support- E.A., O.D.; Supervision- E.A.

Conflict of Interest: Authors declared no conflict of interest.

Financial Disclosure: Authors declared no financial support.

Etik Komite Onayı: Etik komite onayı bu calışma icin, yerel etik komiteden alınmıştır.

Bilgilendirilmiş Onam: Katılımcılardan bilgilendirilmiş onam alınmıştır.

Hakem Değerlendirmesi: Dış bağımsız.

Yazar Katkıları: Çalışma Konsepti/Tasarım- E.A., E.K.; Veri Toplama- E.A., E.K., O.D., H.A.; Veri Analizi/Yorumlama- R.D., D.Ş., H.S., O.D., H.A.; Yazı Taslağı- E.A., E.K.; İçeriğin Eleştirel Incelemesi- R.D., D.Ş., H.S., O.D.; Son Onay ve Sorumluluk- E.K., E.A.; Malzeme ve Teknik Destek- E.A., O.D.; Süpervizyon- E.A.
Çıkar Çatışması: Yazarlar çıkar çatışması beyan etmemişlerdir.

Finansal Destek: Yazarlar finansal destek beyan etmemişlerdir.

\section{REFERENCES}

1. Karkouti K, Dattilo KM. Perioperative hemostasis and thrombosis. Can J Anaesth. 2006;53(12):1260-2. [CrossRef]

2. Clark WR Jr, Leather RP. Hemostasis during liver resections. Surgery 1970;67:556-7.

3. Saifi J, Fortune J, Graca L, Shah D. Benefits of intraabdominal pack placement for the management of nonmechanical hemorrhage. Arch Surg 1990;125:119-22. [CrossRef]

4. Beal S. Fatal hepatic hemorrhage: an unresolved problem in the management of complex liver injuries. J Trauma 1990;30:163-9. [CrossRef]

5. Pringle JG. Notes on the arrest of hepatic hemorrhage due to trauma. Ann Surg 1908;48:541-9. [CrossRef]

6. Carmona RH, Peck DZ, Lim RC Jr. The role of packing and reoperation in severe hepatic trauma. J Trauma 1984;24:77984. [CrossRef]

7. Raccuia JS, Simonian G, Dardik M, et al. Comparative efficacy of topical hemostatic agents in a rat kidney model Am J Surg 1992;163:234-8. [CrossRef]

8. Cobden RH, Thrasher EL, Harris WH. Topical hemostatic agents to reduce bleeding from cancellous bone: a comparison of microcrystalline collagen, thrombin, and thrombin-soaked gelatin foam. J Bone Joint Surg Am 1976;58:70-3. [CrossRef]

9. Fonouni $H$, Kashfi A, Majlesara A, Stahlheber O, Konstantinidis L, Gharabaghi N, Kraus TW, Mehrabi A, Oweira H. Hemostatic efficiency of modern topical sealants: Comparative evaluation after liver resection and splenic laceration in a swine model. J Biomed Mater Res B Appl Biomater. 2017 Jun 23. doi: 10.1002/jbm.b.33937. [Epub ahead of print] [CrossRef]

10. Aleinik A, Baikov A, Dambaev G, Semichev E, Bushlanov P. Liver Hemostasis by Using Cold Plasma. Surg Innov 2017;24(3):253-8. [CrossRef]

11. Jiang $X$, Williams KM, Liauw WS, Ammit AJ, Roufogalis BD, Duke CC, Day RO, McLachlan AJ. Effect of St John's wort and ginseng on the pharmacokinetics and pharmacodynamics of warfarin in healthy subjects. Br J Clin Pharmacol 2004;57(5):592-9. [CrossRef]

12. Kandis H, Karapolat S, Yildirim U, Saritas A, Gezer S, Memisogullari R. Effects of Urtica dioica on hepatic ischemia-reperfusion injury in rats. Clinics (Sao Paulo) 2010;65(12):1357-61. [CrossRef]

13. Silva RR, Oliveira e Silva $D$, Fontes $H R$, Alviano CS, Fernandes PD, Alviano DS. Anti-inflammatory, antioxidant, and antimicrobial activities of Cocos nucifera var. typica. BMC Complement Altern Med 2013;13:107. [CrossRef]

14. Chen SP, Lo SF, Wang YC, Chou TY, Chang KM, Chou LW. Validating Efficacy of Shea Nut Oil Extract in Knee Osteoarthritis Patients. Evid Based Complement Alternat Med 2013;2013:147163. [CrossRef]

15. Lansdown AB, Mirastschijski U, Stubbs N, Scanlon E, Agren MS. Zinc in wound healing: theoretical, experimental, and clinical aspects. Wound Repair Regen 200;15(1):2-16.

16. Basch E, Ulbricht C, Hammerness P, Blevins A, Sollars D Thyme (Thymus vulgaris L.), thymol. J. Herb. Pharmacother. 2004:4:49-67. [CrossRef] 
18. Klemow KM, Bartlow A, Crawford J, Kocher N, Shah J, Ritsick M. Medical Attributes of St. John's Wort (Hypericum perforatum) in Herbal Medicine: Biomolecular and Clinical Aspects. 2nd edition. Benzie IFF, Wachtel-Galor S, editors. Boca Raton (FL): CRC Press/Taylor \& Francis; 2011.

19. Lieberman S. Evidence-based natural medicine: Nutriceutical review of St. John's wort (Hypericum perforatum) for the treatment of depression. J Women's Health 1998;7:177-82. [CrossRef]

20. Schempp CM, Pelz K, Wittmer A, Schopf E, Simon JC. Antibacterial activity of hyperforin from St. John's wort, against multiresistant Staphylococcus aureus and grampositive bacteria. Lancet 1999;353:2129. [CrossRef]

21. Mishenkova EL, Derbentseva NA, Garagulya AD, Litvin LN. Antiviral properties of St. John's wort and preparations produced from it. Transactions of the Congress of Microbiologists of the Ukraine 1975;4:222-322.

22. Schempp C. M, Kirkin V, Simon-Haarhaus B. et al. Inhibition of tumour cell growth by hyperforin, a novel anticancer drug from St. John's wort that acts by induction of apoptosis. Oncogene 2002;21:1242-50. [CrossRef]

23. Sosa S, Pace R, Bornancin A, et al. Topical anti-inflammatory activity of extracts and compounds from Hypericum perforatum L. J Pharm Pharmacol 2007;59(5):703-9. [CrossRef]

24. Ozturk N, Korkmaz S, Ozturk Y. Wound-healing activity of St. John's Wort (Hypericum perforatum L.) on chicken embryonic fibroblasts. J Ethnopharmacol 2007;111(1):33-9. [CrossRef]

25. Francišković $M$, Gonzalez-Pérez R, Orčić $D$, Sánchez de Medina F, Martínez-Augustin O, Svirčev E, Simin N, MimicaDukić N. Chemical Composition and Immuno-Modulatory Effects of Urtica dioica L. (Stinging Nettle) Extracts. Phytother Res 2017;31(8):1183-91. [CrossRef]

26. Kavalali GM. Urtica: therapeutic and nutritional aspects of stinging nettles (volume 37). In Medicinal and Aromatic Plants_Industrial Profiles, Hardman R (ed). 2003. Taylor \& Francis: New York. [CrossRef]
27. Chrubasik J, Roufogalis B, Wagner H, Chrubasik S. A comprehensive review on the stinging nettle effect and efficacy profiles. Part II: Urticae radix Phytomed 2007;14:56879 .

28. Beyazit $Y$, Kurt M, Kekilli M, Goker H, Haznedaroglu IC. Evaluation of hemostatic effects of Ankaferd as an alternative medicine. Altern Med Rev 2010;15(4):329-36.

17. Aysan E, Bektas H, Ersoz F, Sari S, Kaygusuz A, Huq GE. Ability of the ankaferd blood stopper ${ }^{\circledR}$ to prevent parenchymal bleeding in an experimental hepatic trauma model. Int J Clin Exp Med 2010;3(3):186-91.

29. Jones PW, Williams DR. The use and role of zinc and its compounds in wound healing. Met lons Biol Syst 2004;41:139-83. [CrossRef]

30. Vallee $\mathrm{BL}$, Falchuk KH. The biochemical basis of zinc physiology. Physiol Rev 1993;73:79-118. [CrossRef]

31. O'Dell BL. Zinc plays both structural and catalytic roles in metalloproteins. Nutr Rev 1992;50:48-50. [CrossRef]

32. Lansdown ABG, Sampson B, Rowe A. Sequential changes in trace metal, metallothionein and calmodulin concentrations in healing skin wounds. J Anat 1999;195(3):375-86. [CrossRef]

33. Zorrilla P, Gomez LA, Salido JA, Silva A, Lopez-Alonso A. Low serum zinc level as a predictive factor of delayed wound healing in total hip replacement. Wound Repair Regen 2006;14:119-22. [CrossRef]

34. Faure H, Peyrin JC, Richard MJ, Favier A. Parenteral supplementation with zinc in surgical patients corrects postoperative serum-zinc drop. Biol Trace Elem Res 1991;30:37-45. [CrossRef]

35. Braga PC, Dal Sasso M, Culici M, Galastri L, Marceca MT, Guffanti EE: Antioxidant potential of thymol determined by chemiluminescence inhibition in human neutrophils and cell-free systems. Pharmacology 2006;76:61-8. [CrossRef] 